\title{
Surgical management of bronchial stumps in lobar lung transplantation
}

Hidenao Kayawake, MD, Toyofumi F. Chen-Yoshikawa, MD, PhD, Akihiro Aoyama, MD, PhD, Hideki Motoyama, MD, PhD, Masatsugu Hamaji, MD, PhD, Kyoko Hijiya, MD, PhD, and

Hiroshi Date, MD, PhD

\section{ABSTRACT}

Background: The validity of lobar lung transplantation (LT) has been established in both living-donor lobar lung transplantation (LDLLT) and cadaveric-donor lung transplantation (CLT). However, bronchial stump management in lobar LT has not been precisely documented. Thus, we retrospectively analyzed our strategies for bronchial stump management in lobar LT.

Methods: Between June 2008 and August 2016, 145 LTs (72 LDLLTs and 73 CLTs) were performed at our institution. Bronchial stumps were left in 14 LDLLTs. Eight patients underwent bilateral CLTs with downsizing lobectomy. We avoided leaving donor bronchial stumps by lobar-to-lobar bronchial anastomosis, and left recipient bronchial stumps if necessary. We retrospectively reviewed the bronchial stump management methods and outcomes in these 22 patients.

Results: Among the 14 LDLLTs, right-to-left inverted lobar LT and right singlelobe LT with left pneumonectomy were performed in 12 and 2 patients, respectively. Among the 8 CLTs, 11 lobectomies were performed because of oversized grafts and/or localized pneumonia. Twenty-three lobar-to-lobar bronchial anastomoses were performed, and there were 21 recipient bronchial stumps in total. Three bronchial stumps were left in the donor graft, the middle bronchus in all cases. No complications related to lobar-to-lobar bronchial anastomoses were observed. All bronchial stumps healed well without developing a bronchopleural fistula. The 3-year overall survival rate was $88.1 \%$ (95\% confidence interval, $58.8 \%-97.0 \%$ ).

Conclusions: We successfully avoided leaving bronchial stumps in the donor graft, except in the middle bronchus, by performing lobar-to-lobar bronchial anastomoses in lobar LTs. Excellent healing of lobar-to-lobar bronchial anastomoses and bronchial stumps was observed. (J Thorac Cardiovasc Surg 2018;156:451-60)

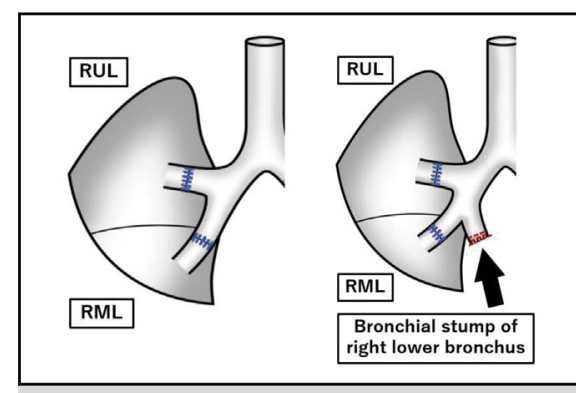

Various anastomotic techniques in cadaveric lobar lung transplantation.

\section{Central Message}

We have successfully managed bronchial stumps in lobar lung transplantation.

\section{Perspective}

In living-donor lobar lung transplantation and downsizing cadaveric-donor lung transplantation, bronchial stump management is a major concern. With lobar-to-lobar bronchial anastomoses, we successfully avoided leaving bronchial stumps in the donor graft, except in the middle bronchus. No complications were encountered. All recipient bronchial stumps healed without developing a bronchopleural fistula.

See Editorial Commentary page 461.
Although the survival rate and outcomes of patients after lung transplantation (LT) have improved over time, donor shortage remains a major unsolved problem as the number of LT candidates is increasing. Another major problem in LT is size mismatch. For small recipients, lobar

\footnotetext{
From the Department of Thoracic Surgery, Kyoto University, Kyoto, Japan. Read at the 97th Annual Meeting of The American Association for Thoracic Surgery, Boston, Massachusetts, April 29-May 3, 2017.

Received for publication April 30, 2017; revisions received Sept 13, 2017; accepted for publication Oct 27, 2017; available ahead of print May 2, 2018

Address for reprints: Hiroshi Date, MD, PhD, Department of Thoracic Surgery, Kyoto University, 54 Shogoin-Kawahara-cho, Sakyo-ku, Kyoto 606-8507, Japan (E-mail: hdate@kuhp.kyoto-u.ac.jp).

$0022-5223 / \$ 36.00$

Copyright (C) 2017 by The American Association for Thoracic Surgery https://doi.org/10.1016/j.jtcvs.2017.10.150
}

cadaveric-donor LT (CLT) is a possible treatment option. ${ }^{1-3}$ Lobar LT increases the available lung supply and allows the use of marginal donor lungs with localized lobar pathology. ${ }^{4}$

Another treatment option, living-donor lobar LT (LDLLT), developed by Starnes et $a{ }^{5}{ }^{5}$ has shown satisfactory outcomes in patients in a rapidly deteriorating

Scanning this QR code will take you to a supplemental video. To view the AATS Annual Meeting Webcast, see the URL next to the webcast thumbnail. 


\section{Abbreviations and Acronyms \\ CI = confidence interval \\ CLT = cadaveric-donor lung transplantation \\ LDLLT $=$ living-donor lobar lung transplantation \\ LT = lung transplantation}

\section{RESULTS \\ LDLLT With Left Bronchial Stumps}

The 14 LDLLTs in which the bronchial stumps were left consisted of 12 right-to-left inverted LDLLTs and 2 single LDLLTs with contralateral pneumonectomy (Table 1). In the right-to-left inverted LDLLTs, the donor's right lower lobe ( 5 segments) was inverted and implanted into the recipient's left chest cavity instead of the donor left lower lobe (4 segments). This procedure was indicated when the total graft forced vital capacity (FVC) was $<60 \%$ of the recipient's predicted FVC or when a donor left lower lobectomy would be technically difficult because of the interlobar pulmonary artery anatomy. The bronchus was anastomosed to the recipient's left upper bronchus, and the left lower bronchial stump was left closed (Figure 1, A). In 2 cases, the recipient's right upper lobe was preserved. There were 7 male and 5 female adult patients, with a mean age of 40.7 years (range, 22-63 years) (Table 1). No limitations were associated with the operative technique of inverted LDLLT itself. In 2 cases, the recipient's left lower bronchial stump was covered with pericardial fat and thymus.

In 2 small pediatric patients, an 8-year-old girl and an 11year-old boy, the right lower lobe or right basal segment was implanted with simultaneous left pneumonectomy to provide more space for an extremely oversized graft (Figure 1, B). In the girl, the left main bronchial stump was covered with pericardial fat after left pneumonectomy.

\section{Bilateral CLT With Downsizing Lobectomy}

Eight bilateral CLTs with downsizing lobectomy were performed in 2 male and 6 female adult patients (mean age, 32.1 years; range, 19-44 years). The reasons for CLT were oversized graft $(n=5)$, lobar infection of the graft $(\mathrm{n}=2)$, or both $(\mathrm{n}=1)$ (Table 2$)$. Eleven downsizing donor lobectomies were performed, including 1 right upper lobectomy, 4 middle lobectomies, 2 right lower lobectomies, 2 left upper lobectomies, and 2 left lower lobectomies. Downsizing donor lobectomy was performed on the back table before implantation in 9 lobectomies. Two middle lobectomies were performed after implantation. Covering of the bronchial stump or bronchial anastomosis was not performed in these cases.

Right upper lobectomy. In the right upper lobectomy, the intermediate bronchus of the donor was anastomosed with the intermediate bronchus of the recipient, and the right upper bronchial stump of the recipient was left closed (Figure 2, A).

Middle lobectomy. In 1 middle lobectomy performed on the back table, the donor's right upper bronchus was anastomosed to the recipient's upper bronchus, and the donor's lower bronchus was separately anastomosed to the recipient's intermediate bronchus. In the other 3 middle lobectomies, bronchial anastomosis was performed at the level 
TABLE 1. Summary of patients who underwent living-donor lobar lung transplantation with residual bronchial stumps

\begin{tabular}{|c|c|c|c|c|c|c|c|c|c|c|}
\hline Patient & Age, y/sex & Disease & Procedure & $\begin{array}{c}\text { Recipient } \\
\text { bronchial } \\
\text { stump }\end{array}$ & $\begin{array}{c}\text { Lobar-to-lobar } \\
\text { bronchial } \\
\text { anastomosis }\end{array}$ & $\begin{array}{c}\text { Outcome } \\
\text { after } \\
\text { transplantation }\end{array}$ & $\begin{array}{c}\text { Covering of } \\
\text { bronchial } \\
\text { stump } \\
\end{array}$ & IS protocol & Antimycotic & $\begin{array}{c}\begin{array}{c}\text { Bacterium } \\
\text { cultured } \\
\text { from sputum }\end{array} \\
\end{array}$ \\
\hline 1 & 43/female & IP & $\begin{array}{l}\text { Left single lobar } \\
\text { Tx (RL } \\
\text { inverted Tx) }\end{array}$ & $\begin{array}{l}\text { Left lower } \\
\text { bronchus }\end{array}$ & 1 & 3 y 1 mo, alive & $\begin{array}{l}\text { Pericardial } \\
\text { fat }\end{array}$ & $\begin{array}{l}\mathrm{FK}+\mathrm{MMF}+ \\
\text { PSL }\end{array}$ & MCFG & None \\
\hline 2 & $37 / \mathrm{male}$ & IP & $\begin{array}{l}\text { Bilateral lobar } \\
\text { Tx (RL } \\
\text { inverted Tx) }\end{array}$ & $\begin{array}{l}\text { Left lower } \\
\text { bronchus }\end{array}$ & 1 & 2 y $11 \mathrm{mo}$, alive & None & $\begin{array}{l}\mathrm{FK}+\mathrm{MMF}+ \\
\quad \mathrm{PSL}\end{array}$ & MCFG & None \\
\hline 3 & $28 /$ male & IP & $\begin{array}{l}\text { Bilateral lobar } \\
\text { Tx (RL } \\
\text { inverted Tx) }\end{array}$ & $\begin{array}{l}\text { Left lower } \\
\text { bronchus }\end{array}$ & 1 & 2 y 9 mo, alive & None & $\begin{array}{l}\mathrm{FK}+\mathrm{MMF}+ \\
\quad \mathrm{PSL}\end{array}$ & MCFG & MRSA \\
\hline 4 & 29/male & $\begin{array}{r}\text { PC after } \\
\text { HSCT }\end{array}$ & $\begin{array}{l}\text { Bilateral lobar } \\
\text { Tx (RL } \\
\text { inverted Tx) }\end{array}$ & $\begin{array}{l}\text { Left lower } \\
\text { bronchus }\end{array}$ & 1 & 2 y 1 mo, alive & None & $\begin{array}{l}\mathrm{FK}+\mathrm{MMF}+ \\
\quad \mathrm{PSL}\end{array}$ & MCFG & $\begin{array}{c}\text { Sphingomonas }(P .) \\
\text { paucinobilis }\end{array}$ \\
\hline 5 & 57/female & Other & $\begin{array}{l}\text { Bilateral lobar } \\
\text { Tx (RL } \\
\text { inverted Tx) }\end{array}$ & $\begin{array}{l}\text { Left lower } \\
\text { bronchus }\end{array}$ & 1 & 1 y $11 \mathrm{mo}$, alive & None & $\begin{array}{l}\mathrm{FK}+\mathrm{MMF}+ \\
\quad \mathrm{PSL}\end{array}$ & MCFG & None \\
\hline 6 & $63 /$ male & IP & $\begin{array}{l}\text { Bilateral lobar } \\
\text { Tx (RU } \\
\text { sparing + RL } \\
\text { inverted Tx) }\end{array}$ & $\begin{array}{l}\text { Left lower } \\
\text { bronchus }\end{array}$ & 2 & 1 y 2 mo, died & None & $\begin{array}{l}\mathrm{FK}+\mathrm{MMF}+ \\
\quad \mathrm{PSL}\end{array}$ & MCFG & $\begin{array}{l}\text { Escherichia coli, } \\
\quad \text { Stenotrophomonas } \\
\text { maltophilia, } \\
\text { Aspergillus } \\
\text { fumigatus }\end{array}$ \\
\hline 7 & $44 / \mathrm{male}$ & $\begin{array}{r}\text { PC after } \\
\text { HSCT }\end{array}$ & $\begin{array}{l}\text { Bilateral lobar } \\
\text { Tx (RL } \\
\text { inverted Tx) }\end{array}$ & $\begin{array}{l}\text { Left lower } \\
\text { bronchus }\end{array}$ & 1 & 1 y 7 mo, alive & Thymus & $\begin{array}{l}\mathrm{FK}+\mathrm{MMF}+ \\
\quad \mathrm{PSL}\end{array}$ & MCFG & None \\
\hline 8 & 24/female & $\begin{array}{r}\text { PC after } \\
\text { HSCT }\end{array}$ & $\begin{array}{l}\text { Bilateral lobar } \\
\text { Tx (RL } \\
\text { inverted Tx) }\end{array}$ & $\begin{array}{l}\text { Left lower } \\
\text { bronchus }\end{array}$ & 1 & 1 y 4 mo, alive & None & $\begin{array}{l}\mathrm{FK}+\mathrm{MMF}+ \\
\quad \mathrm{PSL}\end{array}$ & MCFG & None \\
\hline 9 & $44 /$ male & IP & $\begin{array}{l}\text { Bilateral lobar } \\
\text { Tx (RU } \\
\text { sparing + RL } \\
\text { inverted Tx) }\end{array}$ & $\begin{array}{l}\text { Left lower } \\
\text { bronchus }\end{array}$ & 2 & 1 y 3 mo, alive & None & $\begin{array}{l}\text { CyA }+ \text { MMF + } \\
\text { PSL }\end{array}$ & MCFG & $\begin{array}{r}\text { Enterobacter } \\
\text { aerogenes }\end{array}$ \\
\hline 10 & $22 /$ female & IP & $\begin{array}{l}\text { Bilateral lobar } \\
\text { Tx (RL } \\
\text { inverted Tx) }\end{array}$ & $\begin{array}{l}\text { Left lower } \\
\text { bronchus }\end{array}$ & 1 & 1 y 0 mo, alive & None & $\begin{array}{l}\mathrm{FK}+\mathrm{MMF}+ \\
\quad \mathrm{PSL}\end{array}$ & MCFG & None \\
\hline 11 & $56 /$ male & IP & $\begin{array}{l}\text { Bilateral lobar } \\
\text { Tx (RL } \\
\text { inverted } \mathrm{Tx})\end{array}$ & $\begin{array}{l}\text { Left lower } \\
\text { bronchus }\end{array}$ & 1 & $11 \mathrm{mo}$, alive & None & $\begin{array}{l}\mathrm{CyA}+\mathrm{MMF}+ \\
\text { PSL }\end{array}$ & MCFG & None \\
\hline 12 & $41 /$ female & $\begin{array}{r}\text { PC after } \\
\text { HSCT }\end{array}$ & $\begin{array}{l}\text { Bilateral lobar } \\
\text { Tx (RL } \\
\text { inverted Tx) }\end{array}$ & $\begin{array}{l}\text { Left lower } \\
\text { bronchus }\end{array}$ & 1 & 7 mo, alive & None & $\begin{array}{l}\mathrm{FK}+\mathrm{MMF}+ \\
\quad \mathrm{PSL}\end{array}$ & CPFG & $\begin{array}{r}\text { Pseudomonas } \\
\text { aerguinosa }\end{array}$ \\
\hline 13 & $8 /$ female & $\begin{array}{r}\text { PC after } \\
\text { HSCT }\end{array}$ & $\begin{array}{l}\text { Right single } \\
\text { lobar Tx }+ \\
\text { left } \\
\text { pneumonectomy }\end{array}$ & $\begin{array}{l}\text { Left main } \\
\text { bronchus }\end{array}$ & None & 8 y 5 mo, alive & $\begin{array}{l}\text { Pericardial } \\
\text { fat }\end{array}$ & $\begin{array}{l}\text { CyA }+\mathrm{MMF}+ \\
\text { PSL }\end{array}$ & MCFG & None \\
\hline 14 & $11 / \mathrm{male}$ & $\begin{array}{r}\text { PC after } \\
\text { HSCT }\end{array}$ & $\begin{array}{l}\text { Right basal } \\
\text { segmental } \mathrm{Tx}+ \\
\text { left } \\
\text { pneumonecotmy }\end{array}$ & $\begin{array}{l}\text { Left main } \\
\text { bronchus }\end{array}$ & None & $14 \mathrm{~d}$, died & None & $\begin{array}{l}\text { СyA }+ \text { MMF }+ \\
\text { PSL }\end{array}$ & MCFG & None \\
\hline
\end{tabular}

$I S$, Immunosuppression; $T x$, transplantation; $R L$, right lower lobe; $F K$, tacrolimus; $M M F$, mycophenolate mofetil; $P S L$, predonisolone; $M C F G$, micafungin; $I P$, interstitial pneumonia; MRSA, methicillin-resistant Staphylococcus aureus; PC after HSCT, pulmonary complication after hematopoietic stem cell transplantation; $R U$, right upper lobe; $C y A$, cyclosporine; $C P F G$, caspofungin.

of the right main bronchus, and the donor's middle bronchial stump was left closed (Figure 2, B).

Right lower lobectomy. In 1 right lower lobectomy, the donor's middle bronchus was anastomosed to the intermediate bronchus of the recipient, and the donor's upper bronchus was anastomosed separately to the recipient's upper bronchus (Video 1). In the other right lower lobectomy, a middle bronchus-to-middle bronchus anastomosis was performed while leaving the recipient's right lower bronchial stump closed (Figure 2, C). 


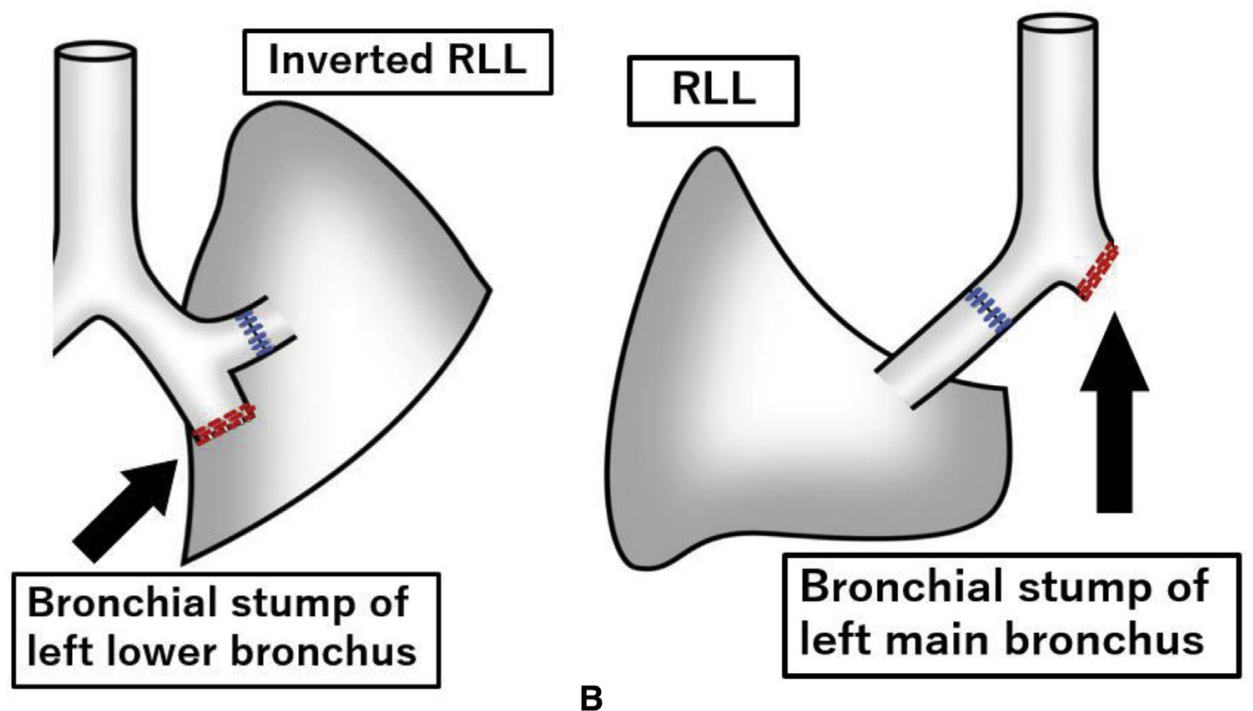

FIGURE 1. The operative technique for creating bronchial anastomoses and bronchial stumps in living-donor lobar lung transplantation (LDLLT). A, In inverted LDLLT, the anastomosis is performed between the left upper bronchus of the recipient and the right lower bronchus of the donor, and the left lower bronchial stump of the recipient is left closed. B, A single LDLLT with contralateral pneumonectomy. Blue lines indicate the bronchial anastomoses, and red lines indicate the bronchial stumps of the recipients. $R L L$, Right lower lobe.

TABLE 2. Summary of patients who underwent cadaveric lung transplantation with downsizing lobectomy

\begin{tabular}{|c|c|c|c|c|c|c|c|c|c|c|c|c|}
\hline Patient & $\begin{array}{l}\text { Age, } \\
\text { y/sex }\end{array}$ & Disease & $\begin{array}{c}\text { Removed } \\
\text { lobe(s) }\end{array}$ & $\begin{array}{c}\text { Recipient } \\
\text { bronchial } \\
\text { stump }\end{array}$ & $\begin{array}{c}\text { Donor } \\
\text { bronchial } \\
\text { stump }\end{array}$ & $\begin{array}{c}\text { Lobar-to- } \\
\text { lobar } \\
\text { bronchial } \\
\text { anastomosis }\end{array}$ & $\begin{array}{l}\text { Reason for } \\
\text { downsizing }\end{array}$ & $\begin{array}{c}\text { Outcome } \\
\text { after } \\
\text { transplantation }\end{array}$ & $\begin{array}{l}\text { Covering } \\
\text { of the } \\
\text { bronchial } \\
\text { stumps or } \\
\text { anastomoses }\end{array}$ & IS protocol & Antimycotic & $\begin{array}{c}\text { Bacterium } \\
\text { cultured from } \\
\text { sputum }\end{array}$ \\
\hline 1 & 24/female & IPAH & $\begin{array}{l}\text { Right middle } \\
\text { lobe }+ \text { left } \\
\text { upper lobe }\end{array}$ & None & $\begin{array}{l}\text { Middle } \\
\text { bronchus }\end{array}$ & None & $\begin{array}{l}\text { Graft } \\
\quad \text { oversize }\end{array}$ & 4 y $11 \mathrm{mo}$, alive & None & $\begin{array}{c}\mathrm{FK}+ \\
\mathrm{MMF}+ \\
\mathrm{PSL}\end{array}$ & MCFG & $\begin{array}{c}\text { Enterobacter } \\
\text { cloacae }\end{array}$ \\
\hline 2 & $39 /$ female & $\mathrm{CF}$ & $\begin{array}{l}\text { Right middle } \\
\text { lobe }\end{array}$ & None & $\begin{array}{l}\text { Middle } \\
\text { bronchus }\end{array}$ & None & $\begin{array}{l}\text { Graft } \\
\quad \text { oversize }\end{array}$ & 3 y $1 \mathrm{mo}$, alive & None & $\begin{array}{l}\text { CyA }+ \\
\quad \text { MMF }+ \\
\quad \text { PSL }\end{array}$ & MCFG & $\begin{array}{l}\text { Burkholderia } \\
\text { cepacia, } \\
\text { MRSA }\end{array}$ \\
\hline 3 & 19/female & IPAH & $\begin{array}{l}\text { Right middle } \\
\text { lobe }\end{array}$ & None & None & 2 & $\begin{array}{l}\text { Graft } \\
\text { oversize }\end{array}$ & 1 y $6 \mathrm{mo}$, alive & None & $\begin{array}{l}\mathrm{FK}+ \\
\quad \mathrm{MMF}+ \\
\quad \mathrm{PSL}\end{array}$ & MCFG & MRSA \\
\hline 4 & 40/male & DPB & $\begin{array}{l}\text { Right upper } \\
\text { lobe }+ \text { left } \\
\text { lower lobe }\end{array}$ & $\begin{array}{c}\text { Right upper } \\
\text { bronchus } \\
\text { and left } \\
\text { lower } \\
\text { bronchus }\end{array}$ & None & 2 & $\begin{array}{l}\text { Graft } \\
\quad \text { oversize }\end{array}$ & 10 mo, alive & None & $\begin{array}{l}\mathrm{FK}+ \\
\quad \mathrm{MMF}+ \\
\quad \mathrm{PSL}\end{array}$ & MCFG & B. cepacia \\
\hline 5 & $44 /$ male & IP & $\begin{array}{l}\text { Right lower } \\
\text { lobe }\end{array}$ & $\begin{array}{r}\text { Right lower } \\
\text { bronchus }\end{array}$ & None & 2 & $\begin{array}{l}\text { Lobar } \\
\quad \text { infection }\end{array}$ & $10 \mathrm{mo}$, alive & None & $\begin{array}{l}\mathrm{FK}+ \\
\quad \mathrm{MMF}+ \\
\quad \mathrm{PSL}\end{array}$ & CPFG & None \\
\hline 6 & $21 /$ male & IPAH & $\begin{array}{l}\text { Right lower } \\
\text { lobe }\end{array}$ & None & None & 2 & $\begin{array}{l}\text { Lobar } \\
\quad \text { infection }\end{array}$ & 9 mo, alive & None & $\begin{array}{l}\mathrm{FK}+ \\
\mathrm{MMF}+ \\
\mathrm{PSL}\end{array}$ & MCFG & None \\
\hline 7 & $33 / \mathrm{male}$ & IP & $\begin{array}{c}\text { Right middle } \\
\text { lobe }+ \text { left } \\
\text { lower lobe }\end{array}$ & $\begin{array}{l}\text { Left lower } \\
\text { bronchus }\end{array}$ & $\begin{array}{l}\text { Middle } \\
\text { bronchus }\end{array}$ & 1 & $\begin{array}{l}\text { Graft } \\
\quad \text { oversize } \\
\text { and lobar } \\
\text { infection }\end{array}$ & 8 mo, alive & None & $\begin{array}{l}\mathrm{FK}+ \\
\mathrm{MMF}+ \\
\mathrm{PSL}\end{array}$ & VRCZ & $\begin{array}{c}\text { Pseudomonas } \\
\text { aerguinosa, } \\
\text { B cepacia, } \\
\text { E cloacae }\end{array}$ \\
\hline 8 & $37 /$ female & IPAH & Left upper lobe & None & None & None & $\begin{array}{l}\text { Graft } \\
\text { oversize }\end{array}$ & $8 \mathrm{mo}$, alive & None & $\begin{array}{l}\mathrm{FK}+ \\
\quad \mathrm{MMF}+ \\
\quad \mathrm{PSL}\end{array}$ & MCFG & None \\
\hline
\end{tabular}

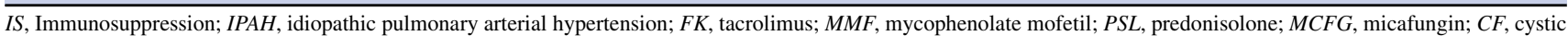
fibrosis; $C y A$, cyclosporine; $M R S A$, methicillin-resistant Staphylococcus aureus; DPB, diffuse panbronchiolitis; IP, interstitial pneumonia; $C P F G$, caspofungin; VRCZ, voriconazole. 


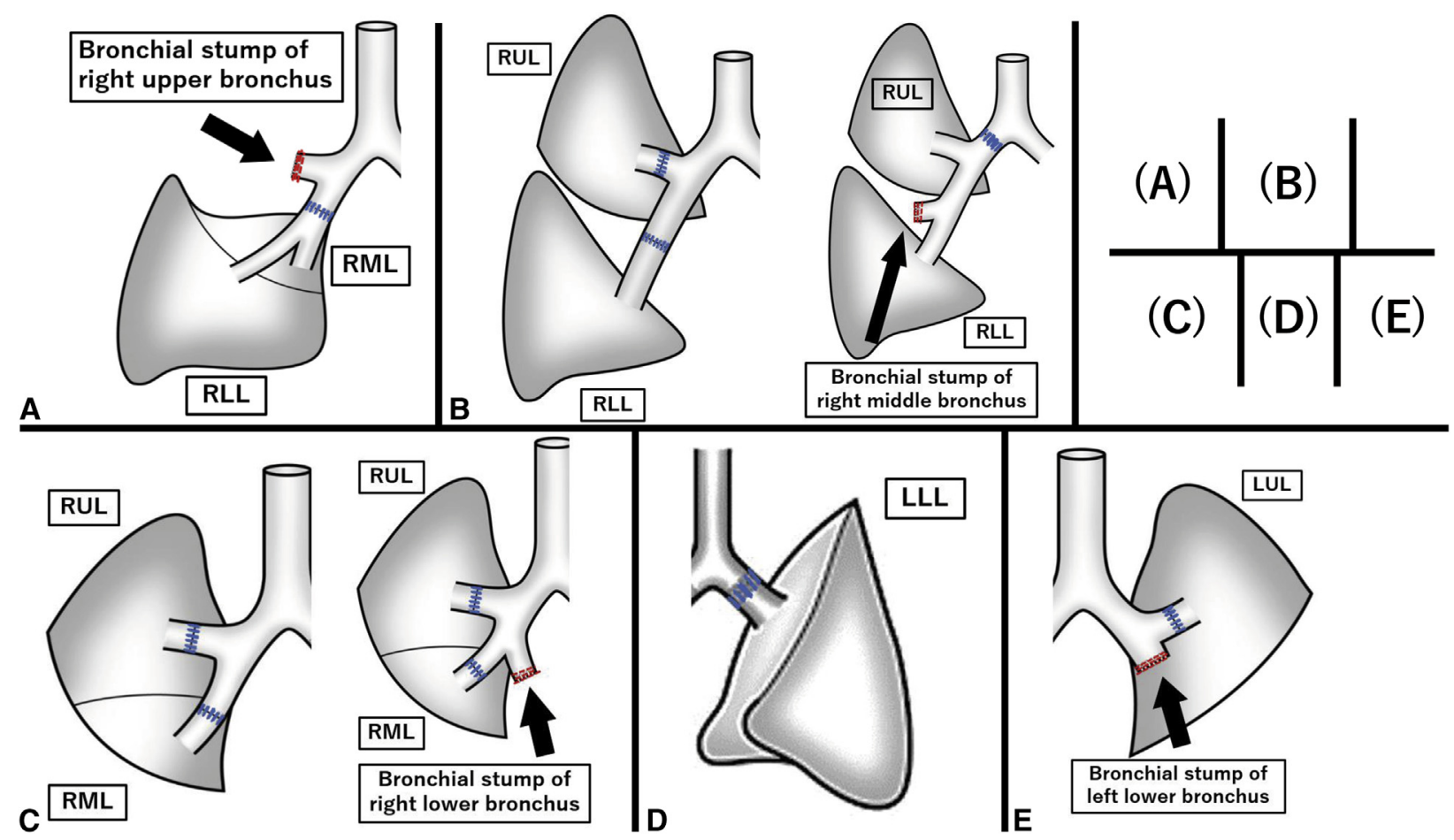

FIGURE 2. Various operative techniques of bilateral cadaveric-donor lobar lung transplantation (CLT) with downsizing lobectomy: bilateral CLT with right upper lobectomy (A), middle lobectomy (B), right lower lobectomy (C), left upper lobectomy (D), and left lower lobectomy (E). Blue lines indicate the bronchial anastomoses, and red lines indicate the bronchial stumps of the recipients. $R M L$, Right middle lobe; $R L L$, right lower lobe; $R U L$, right upper lobe; $L L L$, left lower lobe; $L U L$, left upper lobe.

Left upper lobectomy. In 1 left upper lobectomy, the bronchial anastomosis was performed at the level of the left main bronchus (Figure 2, D).

Left lower lobectomy. In 1 left lower lobectomy, the donor's upper bronchus was anastomosed to the recipient's upper bronchus, and the recipient's left lower bronchus was left closed (Figure 2,E).

\section{Healing of the Bronchial Stumps and Anastomoses}

In the 22 patients, 23 lobar-to-lobar bronchial anastomoses were performed, and 21 recipient bronchial stumps were left. Three bronchial stumps were left in the donor graft, all of which were middle bronchus stumps. There were no complications related to lobar-to-lobar bronchial anastomoses. All bronchial stumps healed well, without developing a bronchopleural fistula. The bronchoscopic findings in representative cases are shown in Figure 3.

\section{Immunosuppression and Antibiotic/Antimycotic Protocols}

A combined treatment with tacrolimus, mycophenolate mofetil, and prednisolone was used for immunosuppression in most patients. In a few patients, cyclosporine was used instead of tacrolimus. In most patients, cefozopran was the antibiotic agent and micafungin was the antimycotic agent. All patients routinely inhaled amphotericin B. One patient had an Aspergillus fumigatus infection, but bronchial healing proceeded without complications.

\section{Outcomes and Prognosis}

Among the 22 patients, 1 pediatric patient who underwent right basal segmental LDLLT with left pneumonectomy died from septic shock on postoperative day 14 . This patient was on extracorporeal membrane oxygenation during the postoperative period because of primary graft dysfunction. One adult patient who underwent right-toleft inverted LDLLT died from chronic lung allograft dysfunction 1 year after LDLLT. Neither of these patients had any complications related to the bronchial stumps. The remaining 20 living patients showed no such complications, and excellent healing of the bronchial anastomoses and stumps was observed. The 1-year and 3-year overall survival rates were $95.5 \%$ (95\% confidence interval $[\mathrm{CI}]$, $71.9 \%-99.3 \%$ ) and $88.1 \%$ (95\% CI, $58.8 \%-97.0 \%)$, respectively (Figure 4).

\section{DISCUSSION}

Lobar LT was first reported on living donors. ${ }^{9} 10$ It was soon used with cadaveric lungs to overcome size 


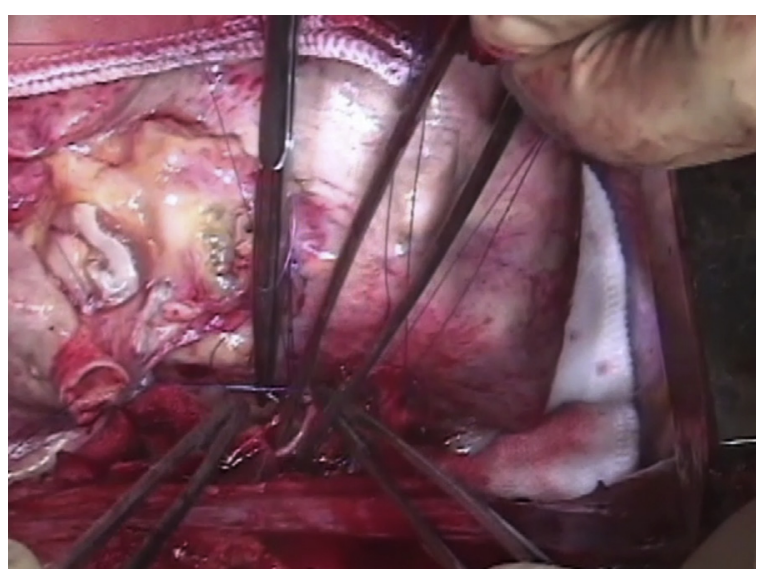

VIDEO 1. Bilateral cadaveric-donor lung transplantation in a 21-year-old woman with idiopathic pulmonary arterial hypertension. She underwent cadaveric-donor lobar lung transplantation with donor right lower lobectomy because of pneumonia of the right lower lobe. The video starts at the donor right lower lobectomy on the back table. After right pneumonectomy, the right donor graft was placed into the patient's right chest cavity. The bronchial anastomosis was started by anastomosing the middle bronchus of the donor to the intermediate bronchus of the recipient. Because of the difference in diameter between the intermediate bronchus of the recipient and the middle bronchus of the donor, the intermediate bronchus was reefed using 4-0 PDS sutures to adjust the diameter. The anastomosis between the intermediate bronchus and the middle bronchus was performed, followed by anastomosis between the right upper bronchi of the donor and recipient and then anastomoses of the pulmonary vein and artery. After reperfusion, the implanted lobes were fully expanded without atelectasis. Video available at: https://www.jtcvs.org/article/S0022-5223(17) 32854-4/fulltext.

discrepancies. ${ }^{11,12}$ Lobar LT is a technically demanding procedure that nevertheless has been increasingly performed at some institutions with satisfactory outcomes. ${ }^{13-16}$ However, life-threating complications, including bronchial fistula, have been reported. ${ }^{17,18}$ Our techniques of bronchial management are unique in that we allow leaving a recipient's bronchial stump and avoid leaving donor bronchial stumps by using lobar-to-lobar bronchial anastomosis.

LDLLT plays an important role in dealing with the severe shortage of suitable cadavers in countries like Japan. ${ }^{5,19}$ In standard LDLLT, bronchial anastomosis is usually performed between the lower bronchus of the donor and the main bronchus of the recipient; therefore, there are no stumps left. Successful healing of bronchial anastomoses in LDLLT has been already reported. ${ }^{7}$ In LDLLT, size discrepancies between donors and recipients are often a problem. The two lobes are often too small, especially for adult patients. To overcome this problem of size mismatch, we developed a right-to-left inverted LDLLT technique that exploits the fact that the right lower lobe is $25 \%$ larger than the left lower lobe. ${ }^{6}$ When the right lower lobe graft is inverted, the donor pulmonary artery is positioned posteriorly to the donor lower bronchus. In contrast, the left main pulmonary artery of the recipient is located anteriorly to the recipient main bronchus. The recipient's upper bronchus is selected for bronchial anastomosis so that the pulmonary artery can be anastomosed behind the bronchial anastomosis. As a result, the recipient's lower bronchus is left closed. Great care was taken to preserve bronchial artery circulation by careful dissection around the bronchial stump. The distance between the lower bronchial stump and the lobar-to-lobar bronchial anastomosis was maintained at $>7 \mathrm{~mm}$ to avoid ischemic changes around the second carina. We also ensured that the left main bronchus and the left upper bronchus were approximately straight while stapling the left lower bronchus of the recipient to avoid narrowing of the bronchial airway. On postoperative bronchoscopy, the inverted right lower bronchus appeared straight in the vicinity of the left main bronchus of the recipient (Figures 1, $A$ and 3, $A$ ).

Conversely, when LDLLT is considered for pediatric patients, the 2 lobes from adult donors are often too large. In these cases, we performed single LDLLT with satisfactory outcomes. ${ }^{7,19}$ However, we sometimes experienced cases in which even 1 implanted adult donor lobe was too large to close the chest cavity of the recipient. In such cases, we often performed delayed chest closure, ${ }^{20}$ whereas for an extremely oversize graft, we performed right single LDLLTs with left pneumonectomy. ${ }^{21}$ Although this operative method left a left main bronchial stump, no stumprelated complications were observed (Figure 1,B).

In CLTs, local pathologies of marginal donors and grafts that are too large for recipients sometimes become major problems. To utilize as many cadaveric donors as possible and to overcome size discrepancies, CLTs with downsizing lobectomy have been performed at some institutions. ${ }^{1-3,22-24}$ In CLTs, the management of bronchial stumps is of great concern because of reported cases of bronchopleural fistula after CLT, which occurred at the right lower bronchial stump of the donor after right lower lobectomy. ${ }^{17,18}$ Therefore, a key to the success of CLT is the management of the donor's bronchial stump.

Our approach was to avoid leaving donor bronchial stumps by lobar-to-lobar bronchial anastomosis. Antegrade bronchial circulation is lost at the time of donor lung extraction. Therefore, the viability of the donor bronchus depends on retrograde blood supply from the pulmonary artery. If a donor bronchial stump is left in the graft, a potentially higher risk for bronchial stump dehiscence needs to be kept in mind. To avoid leaving donor's bronchial stumps, we performed lobectomies on the back table. The lobe to be removed was selected by visual assessment while the donor lung was still inflated. The extents of size discrepancy and local lung damage, such as lobar infection, were carefully assessed macroscopically. Once the target lobe was removed on the back table, the graft lobar 

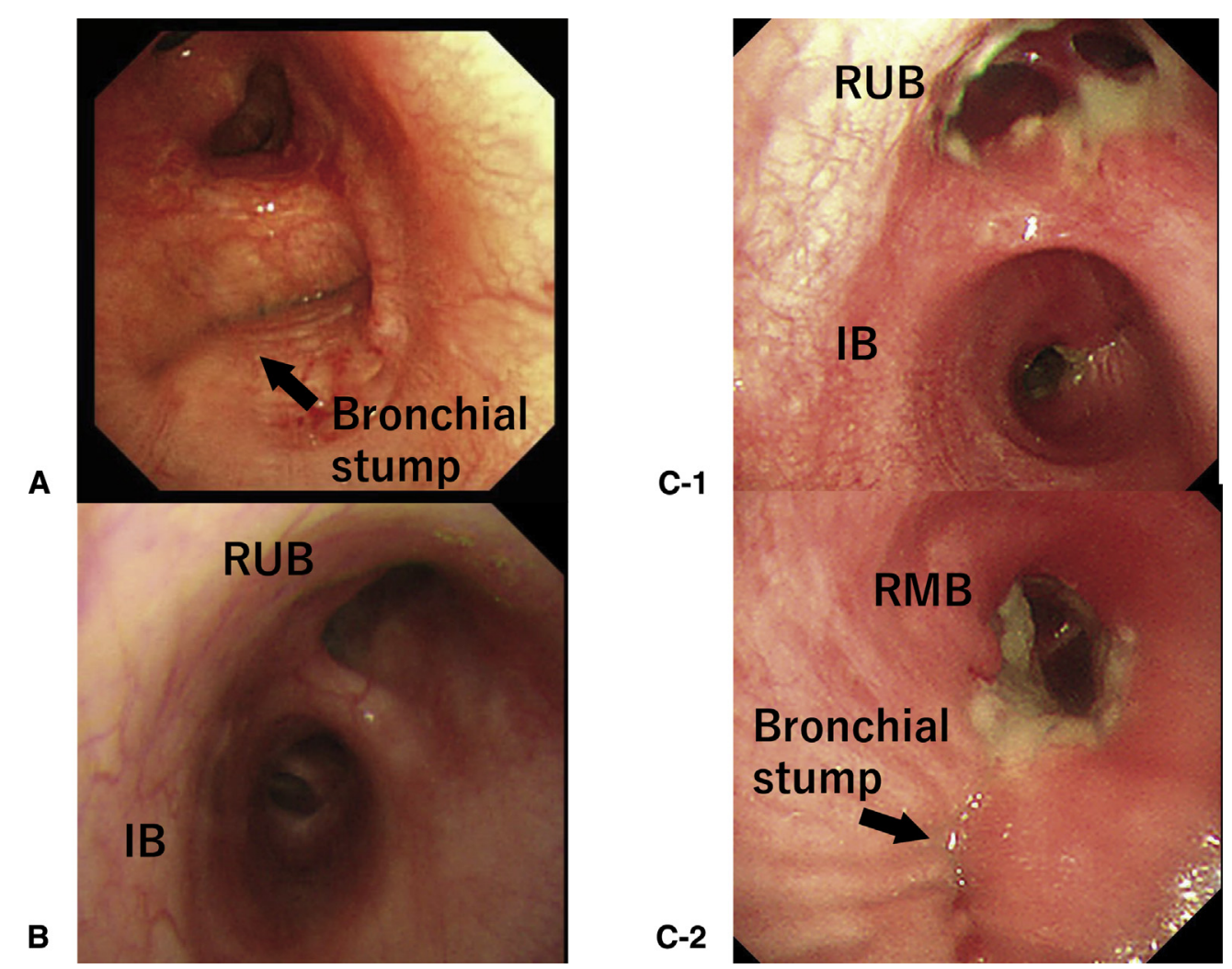

FIGURE 3. Bronchoscopic findings in inverted living donor lobar lung transplantation (LDLLT) and cadaveric-donor lobar lung transplantation (CLT) with downsizing lobectomy. A, At 1 month after inverted LDLLT, healing of the left lower bronchial stump of the recipient was favorable. The inverted right lower bronchus was positioned straight toward the left main bronchus of the recipient. B, Anastomoses between the donor's and the recipient's right upper bronchi and between the intermediate bronchus of the recipient and the lower bronchus of the donor at 1 year after CLT with middle lobectomy. No bronchial stumps remained, and healing of the bronchial anastomoses was excellent. C, Lobar-to-lobar anastomoses in the right upper bronchus and middle bronchus with the right lower bronchial stump 2 weeks after CLT with right lower lobectomy. Healing of the bronchial anastomoses and the bronchial stump was favorable. $R U B$, Right upper bronchus; $I B$, intermediate bronchus; $R M B$, right middle bronchus.

bronchus was transected as far to the periphery as possible to reduce the risk of ischemic changes. In recipient pneumonectomy, each lobar bronchus was stapled separately

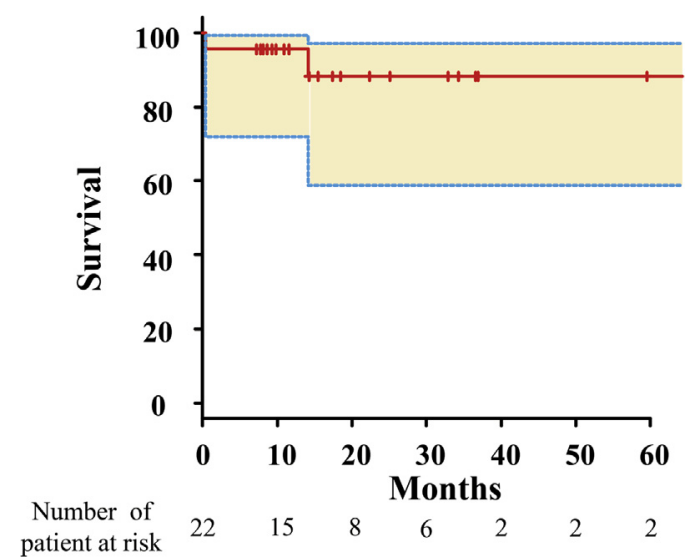

FIGURE 4. Actuarial survival rate of the 22 patients calculated using the Kaplan-Meier method. The 1-year and 3-year overall survival rates were $95.5 \%$ (95\% confidence interval, $71.9 \%-99.3 \%)$ and $88.1 \%$ (95\% confidence interval, $58.8 \%-97.0 \%$ ), respectively. so that it could be trimmed back to near its origin for subsequent lobar-to-lobar bronchial anastomosis. Meticulous attention was paid to preserving the peribronchial tissue close to the bronchial edge. If downsizing lobectomy is to be done after implantation, middle lobectomy should be the choice, given the reports of a relatively safe procedure leaving the donor middle bronchial stump. ${ }^{14,25}$ The middle bronchial stump in the donor graft would be covered by the remaining upper and lower lobes. We found that lobar-to-lobar bronchial anastomosis was technically straightforward and healed without any complications. In cases of donor right lower lobectomy or middle lobectomy, 2 separate lobar-to-lobar bronchial anastomoses were performed. The resulting increase in the duration of operation by 10 to 15 minutes was not clinically important.

We left the recipient's bronchial stump closed if necessary. There were obvious concerns regarding whether a bronchial fistula would develop in immunosuppressed patients. Preserving bronchial artery circulation around the bronchial stump resulted in healing of all recipient 
bronchial stumps without the development of bronchial fistulas. In contrast to the donor bronchus, antegrade oxygenated blood supply to the stump was the key to satisfactory healing.

Regarding the downsizing procedure, although there have been some reports on LT with nonanatomic volume reduction, ${ }^{26,27}$ we usually prefer anatomic resection (lobectomy) to nonanatomic resection. The reduction of lung volume seems to be greater in lobectomy compared with nonanatomic resection. We are also concerned about potential intraoperative and postoperative bleeding from staple lines when performing nonanatomic resection. Indeed, lobectomy has some operative risks for the bronchial stumps, but lobar-to-lobar anastomosis technique and leaving the recipient's bronchial stumps, if necessary, can decrease the operative risks. Finally, when the graft oversize is relatively mild, nonanatomic wedge resection would be suitable.

Regarding the bronchial complications, 11 of the 145 LT recipients developed complications related to bronchial anastomoses $(7.6 \%)$, and bronchial dehiscence occurred in 2 patients. None of these complications were fatal, however. Most notably, there have been no complications related to lobar-to-lobar anastomoses or bronchial stumps. This could be attributed to some extent to the antibiotic/antimycotic protocol. ${ }^{28,29}$ Although the definition of bronchial complication differs among investigators, our results are comparable to outcomes in other patient series. ${ }^{30}$

Limitations of the present study include its nonrandomized, retrospective, single-center design and a relatively small number of transplant procedures evaluated. Another limitation is the variations of recipients included in this study. Indeed, the patients undergoing LDLLT are usually sicker than those undergoing CLT, and some patients underwent emergent LDLLT. However, some patients undergoing CLT are also quite sick at the time of transplantation because of the disease progression during the waiting period, especially in Japan, where the average waiting time is approximately 830 days. To save these quite sick patients, even if the benefit is marginal, CLT should be done because of the severe donor shortage, especially in Japan.

Finally, the excellent mid-term survival of $88.1 \%(95 \%$ CI, $58.8 \%-97.0 \%$ ) at 3 years is very encouraging.

\section{CONCLUSIONS}

We successfully avoided leaving bronchial stumps in the donor graft, except in the middle bronchus, by performing lobar-to-lobar bronchial anastomoses in CLTs, with favorable outcomes. Healing of the lobar-to-lobar bronchial anastomoses and bronchial stumps in lobar LT was excellent. Leaving the recipient's bronchial stump appears to be a safe practice.

\section{Webcast}

You can watch a Webcast of this AATS meeting presentation by going to: https://aats.blob.core.windows.net/ media/17AM/2017-05-02/RM302-304/05-02-17_Room 302-304_1649_Kayawake.mp4.

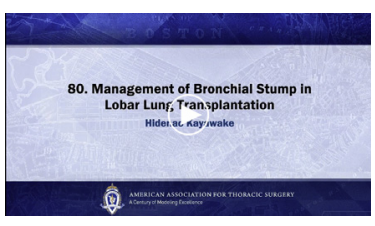

\section{Conflict of Interest Statement}

Authors have nothing to disclose with regard to commercial support.

\section{References}

1. Inci I, Schuurmans MM, Kestenholz P, Schneiter D, Hillinger S, Opitz I, et al Long-term outcomes of bilateral lobar lung transplantation. Eur J Cardiothorac Surg. 2013;43:1220-5.

2. Shigemura N, D'Cunha J, Bhama JK, Shiose A, Abou El Ela A, Hackmann A, et al. Lobar lung transplantation: a relevant surgical option in the current era of lung allocation score. Ann Thorac Surg. 2013;96:451-6.

3. Toyoda Y. Cadaveric donor lobar lung transplantation for patients on extracorporeal membrane oxygenation as bridge-to-transplant. Gen Thorac Cardiovasc Surg. 2013;61:197-200.

4. Aigner C, Winkler G, Jaksch P, Ankersmit J, Marta G, Taghavi S, et al. Sizereduced lung transplantation: an advanced operative strategy to alleviate donor organ shortage. Transplant Proc. 2004;36:2801-5.

5. Starnes VA, Barr ML, Cohen RG, Hagen JA, Wells WJ, Horn MV, et al. Livingdonor lobar lung transplantation experience: intermediate results. J Thorac Cardiovasc Surg. 1996;112:1284-91.

6. Chen F, Miyamoto E, Takemoto M, Minakata K, Yamada T, Sato M, et al. Right and left inverted lobar lung transplantation. Am J Transplant. 2015;15:1716-21.

7. Date H, Aoyama A, Hijiya K, Motoyama H, Handa T, Kinoshita H, et al. Outcomes of various transplant procedures (single, sparing, inverted) in livingdonor lobar lung transplantation. J Thorac Cardiovasc Surg. 2017;153:479-86.

8. Kanda Y. Investigation of the freely available easy-to-use software 'EZR' for medical statistics. Bone Marrow Transplant. 2013;48:452-8.

9. Goldsmith MF. Mother to child: first living donor lung transplant. JAMA. 1990; 264:2724.

10. Starnes VA, Barr ML, Cohen RG. Lobar transplantation. Indications, technique, and outcome. J Thorac Cardiovasc Surg. 1994;108:403-10; discussion 410-1.

11. Bisson A, Bonnette P, Perruchoud A, Leroy M, Colchen A, Raffin L, et al. Left lower lobe transplantation during a bilateral single lung transplantation (pulmonary lobe transplantation). Eur J Cardiothorac Surg. 1992;6:568-70.

12. Bisson A, Bonnette P, el Kadi NB, Leroy M, Colchen A. Bilateral pulmonary lobe transplantation: left lower and right middle and lower lobes. Ann Thorac Surg. 1994;57:219-21.

13. Bharat A, Patterson GA. Merits of cadaveric lobar lung transplantation. Eur J Cardiothorac Surg. 2013;43:1225-6.

14. Slama A, Ghanim B, Klikovits T, Scheed A, Hoda MA, Hoetzenecker K, et al. Lobar lung transplantation - is it comparable with standard lung transplantation? Transplant Int. 2014;27:909-16.

15. Santos F, Lama R, Alvarez A, Algar FJ, Quero F, Cerezo F, et al. Pulmonary tailoring and lobar transplantation to overcome size disparities in lung transplantation. Transplant Proc. 2005;37:1526-9.

16. Couetil JP, Tolan MJ, Loulmet DF, Guinvarch A, Chevalier PG, Achkar A, et al. Pulmonary bipartitioning and lobar transplantation: a new approach to donor organ shortage. J Thorac Cardiovasc Surg. 1997;113:529-37.

17. Brioude G, D'journo XB, Reynaud-Gaubert M, Thomas PA. Bronchial fistula after lobar size reduction for bilateral lung transplantation in Kartagener's syndrome: a surgical challenge. Interact Cardiovasc Thorac Surg. 2013;17:184-6. 
18. D’Angelo A, Bhama JK, Crespo M, Pilewski J, Shigemura N, Bermudez C, et al. Bronchopleural fistula after bilateral sequential lobar lung transplantation: technical details of a successful repair. J Thorac Cardiovasc Surg. 2015;149:e67-8.

19. Date H, Sato M, Aoyama A, Yamada T, Mizota T, Kinoshita H, et al. Livingdonor lobar lung transplantation provides similar survival to cadaveric lung transplantation even for very ill patients. Eur J Cardiothorac Surg. 2015;47:967-72; discussion 972-3

20. Chen F, Matsukawa S, Ishii H, Ikeda T, Shoji T, Fujinaga T, et al. Delayed chest closure assessed by transesophageal echocardiogram in single-lobe lung transplantation. Ann Thorac Surg. 2011;92:2254-7.

21. Sonobe M, Bando T, Kusuki S, Fujinaga T, Shoji T, Chen F, et al. Living-donor single-lobe lung transplantation and simultaneous contralateral pneumonectomy in a child. J Heart Lung Transplant. 2011;30:471-4.

22. Benden C, Inci I, Weder W, Boehler A. Size-reduced lung transplantation in children-an option worth to consider! Pediatr Transplant. 2010;14:529-33.

23. Raja S, Murthy SC, Pettersson GB, Mason DP. Managing extreme airway size mismatch in lung transplantation: the "upper lobectomy" technique. Semin Thorac Cardiovasc Surg. 2011;23:336-8.

24. Marasco SF, Than S, Keating D, Westall G, Whitford H, Snell G, et al. Cadaveric lobar lung transplantation: techinical aspects. Ann Thorac Surg. 2012;93: 1836-42.

25. Egan TM, Thompson JT, Detterbeck FC, Lackner RP, Mill MR, Ogden WD, et al. Effect of size (mis)matching in clinical double-lung transplantation. Transplantation. 1995;59:707-13

26. Wisser W, Klepetko W, Wekerle T, Laufer G, Stift A, Hiesmayr M, et al. Tailoring of the lung to overcome size disparities in lung transplantation. J Heart Lung Transplant. 1996;15:239-42.

27. Shigemura N, Bermudez C, Hattler BG, Johnson B, Crespo M, Pilewski J, et al. Impact of graft volume reduction for oversized grafts after lung transplantation on outcome in recipients with end-stage restrictive pulmonary diseases. J Heart Lung Transplant. 2009;28:130-4.

28. Ludwig C, Riedel R, Schnell J, Stoelben E. Inhalation with Tobramycin to improve healing of tracheobronchial reconstruction. Eur J Cardiothorac Surg. 2009;35:797-800; discussion 800.

29. Herrera JM, McNeil KD, Higgins RS, Coulden RA, Flower CD, Nashef SA, et al. Airway complications after lung transplantation: treatment and long-term outcome. Ann Thorac Surg. 2001;71:989-93; discussion 993-4.

30. Backhus LM, Sievers EM, Schenkel FA, Barr ML, Cohen RG, Smith MA, et al. Pleural space problems after living lobar transplantation. J Heart Lung Transplant. 2005;24:2086-90.

Key Words: bronchial stump, complication, lobar lung transplantation, management

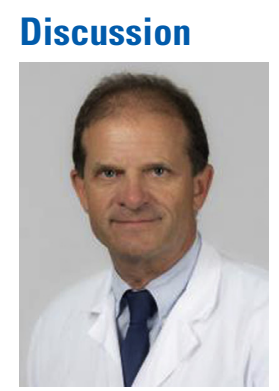

Dr Walter Weder (Zurich, Switzerland). I thank the AATS for giving me the opportunity to discuss this presentation and paper and congratulate Dr Kayawake and the team from Kyoto University for this interesting concept, analysis of their data and excellent results.

I have a few questions. To my knowledge, you are one of the few groups that perform bronchial anastomosis at the level of the recipient lobar bronchus, and this is well in situations where it would be possible to perform an end-to-end anastomosis from the donor lobe bronchus into the main bronchus. In our hands, end-to-end anastomosis from the lobe to the main bronchus or in bilobar transplantation from the donor intermediate to the main bronchus works without problems and with excellent results. So what is the rationale behind your approach?

Dr Hidenao Kayawake (Kyoto, Japan). Thank you for your question. In lung transplantation, the bronchial tissues, including bronchial arteries, are also cut down when the bronchus is transected. Therefore, antegrade blood flow for donor bronchus is lost, and the blood flow for bronchial anastomosis depends only on retrograde blood supply from pulmonary arteries. From this point, we perform bronchial anastomosis as peripherally as possible, near the lung parenchyma, using lobar-to-lobar anastomosis technique. There is no bronchial stenosis requiring dilation or a stent in lobar-to-lobar anastomosis to date.

Dr Weder. In terms of blood supply, if you would do a lobar anastomosis directly to the main bronchus, you would not have any difference in terms of blood supply.

My second question. You reinforce a recipient bronchial stump after closing with a linear stapler with several Prolene 4-0 stitches. Why do you need to reinforce the staple line? Do you use this technique as well in lung cancer resection?

Dr Kayawake. There are always concerns regarding whether bronchial fistula would develop in immunosuppressed patients. It is necessary to say, we did not know if additional Prolene stitches were necessary. We always use them expecting additional strength.

Regarding lung cancer surgery, we use additional stitches only for high-risk patients, such as after induction chemoradiotherapy or diabetes mellitus.

Dr Weder. In patients with right upper lobectomy, you leave a bronchial stump on the donor bronchus. Why don't you resect at the intermediate bronchus and perform directly an anastomosis to the right main bronchus?

Dr Kayawake. If the anastomosis is performed at the level of the right main bronchus, the donor graft would be positioned toward the apex. We were concerned that the middle lobar pulmonary vein might be stretched after left atrial anastomosis. We recognize that your team's approach is successful bronchial anastomosis at the level of the right main bronchus in this setting.

Dr Weder. My last question. You mentioned that you leave a distance from the lower bronchial anastomosis to the lower bronchial stump of the recipient of more than $7 \mathrm{~mm}$ to avoid an ischemic problem. Do you not observe secretion accumulation in this lung stump, which causes a problem in an immunocompromised patient?

Dr Kayawake. Bronchoscopic examination showed that there was no deep pocket around the bronchial stump and minimum secretion was observed.

Dr Weder. Finally, I want to congratulate once more Hiroshi Date's team for the excellent short- and long-term survival rate. Thank you very much. 


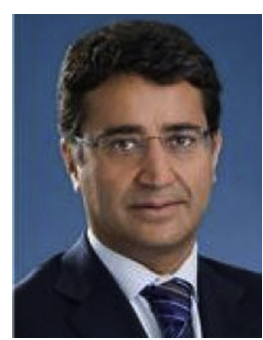

Dr Shaf Keshavjee (Toronto, Ontario, Canada). I want to rise to, first of all, congratulate Hiroshi Date and his team on the incredible work and have the utmost respect for your team and your technical abilities in doing lobar transplants in particularly high-risk patients and high-risk live donors, which we don't have to suffer through, but I do disagree with the technique of doing all these lobar anastomoses. We have done a lot of lobar transplants, we do it as a downsizing technique for our pediatric and small adults, and you can always put the lobar orifice to the main bronchus. The only time that I have been forced to have a stump-and that's why I was very interested in your paper because you have shown it is possible and you can do it safely-is when I had to resect a right lower lobe that had a pneumonia and we were left with the middle and upper lobe to implant. And normally I would also get rid of the middle lobe, but this was a rather large middle lobe and a small upper lobe, so in balance it forced us to leave a stump on the donor lung. But I really do think that your drawings and your comments will make the audience think that it is not possible to do a lobar-to-main bronchus anastomosis, and your concern about the vascular anatomy is unfounded. It is almost always possible to figure out and anastomose it without a kink. It's just an alternative view.

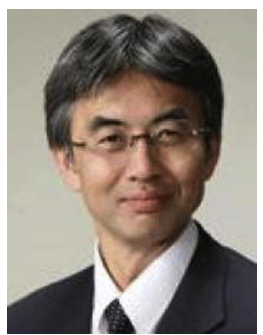

Dr Hiroshi Date (Kyoto, Japan). Shaf, have you ever done any right upper and middle lobe implantation on the right side?

Dr Keshavjee. Yes.

Dr Date. And how did you do that? Did you leave the stump of the right lower bronchus on the donor side when you do a right upper and middle lobe implant?

Dr Keshavjee. That was the only time where I was forced to leave a stump, because I wanted to keep the middle lobe. In other states we have usually just calculated the lung volume. For example, when we have done two upper lobes in one recipient and the two lower lobes to the other recipient of one donor lung, we have either let the middle lobe go with the lower lobe, which is easy to do, or sacrifice the middle lobe and just do two upper and two lower lobes. 